\title{
The blast performance of real-scale reinforced concrete specimens with varying fiber types and content
}

\author{
M. Kovar, M. Foglar \& R. Hajek \\ Faculty of Civil Engineering, Czech Technical University in Prague, \\ Czech Republic
}

\begin{abstract}
According to recent publications, from 2005 to 2008 there were more than 13,000 terrorist attacks around the world, which took more than 73,000 human lives. The attacks were targeted mainly on the technical and civic infrastructure, like governmental buildings, bridges, etc. Due to improved ductility, fibrereinforced concrete (FRC) shows better performance under blast and impact loading compared to conventionally reinforced concrete. Also higher concrete strength shows better blast performance. Field tests of FRC and reinforced concrete specimens were performed in cooperation with the Czech Army corps in the military training area Boletice. The test were performed using real scale reinforced concrete precast slabs $(6 \times 1.5 \times 0.3 \mathrm{~m})$ with varying fiber content, fiber type, fiber strength and concrete strength class and $25 \mathrm{~kg}$ of TNT charges placed in distance from the slab for better simulation of real in-situ conditions. The paper presents conclusions from three sets of tests from years 2010, 2011 and 2013. Eleven specimens were tested in total. Two specimens were without fibers and had different concrete strength. Polypropylen fibers with length $54 \mathrm{~mm}$ and strength of $600 \mathrm{MPa}$ and steel fibers with low ductility $25 \mathrm{~mm}$ long and strength $400 \mathrm{MPa}$ were added in different content $(0.5 \%$ and $1 \%)$ to the other nine specimens.
\end{abstract}

Keywords: blast loading, fiber reinforced concrete.

\section{Introduction}

Due to improved ductility, fiber-reinforced concrete (FRC) shows better performance under blast and impact loading compared to conventionally 
reinforced concrete, as mentioned in Foglar and Kovar [1], Coughlin et al. [2] and Tabatabaei et al. [3].

The experiments from year 2013 determine blast performance of FRC with low strength and low ductility steel fibers (strength $400 \mathrm{MPa}$ ).

This paper continues results presented in Foglar and Kovar [1].

\section{Specimens and material}

Dimensions of the specimens were designed in real scale of a small span bridge as concrete slabs, $6 \mathrm{~m}$ long, $1.5 \mathrm{~m}$ wide and $0.3 \mathrm{~m}$ thick.

Six specimens were made in total, where three of them were made of C30/37 grade concrete $\left(f_{c, \text { cyl }}=30 \mathrm{MPa}\right)($ specimen No. 8, 9 and 10), three of C55/67 grade concrete $\left(f_{c, c y l}=55 \mathrm{MPa}\right)($ No. 6, 7and 11). Steel fibers (FE) $25 \mathrm{~mm}$ long with strength $400 \mathrm{MPa}$ and polypropylene (PP) $54 \mathrm{~mm}$ long synthetic fibers with strength $600 \mathrm{MPa}$ were used. The fiber dosage was following: specimen No. 680 $\mathrm{kg} / \mathrm{m}^{3} \mathrm{FE}$ fibers, No. $740 \mathrm{~kg} / \mathrm{m}^{3} \mathrm{FE}+4.5 \mathrm{~kg} / \mathrm{m}^{3}$ PP fibers, No.8 $40 \mathrm{~kg} / \mathrm{m}^{3} \mathrm{FE}+$ $4.5 \mathrm{~kg} / \mathrm{m}^{3}$ PP fibers, No. $940 \mathrm{~kg} / \mathrm{m}^{3}$ FE fibers, No. $1080 \mathrm{~kg} / \mathrm{m}^{3}$ FE fibers and No. $1140 \mathrm{~kg} / \mathrm{m}^{3}$ FE fibers. The dosage of the fibers was kept low as it can be achieved on-site.

The layout of the experiment was practically the same as experiments from years 2010 and 2011 .

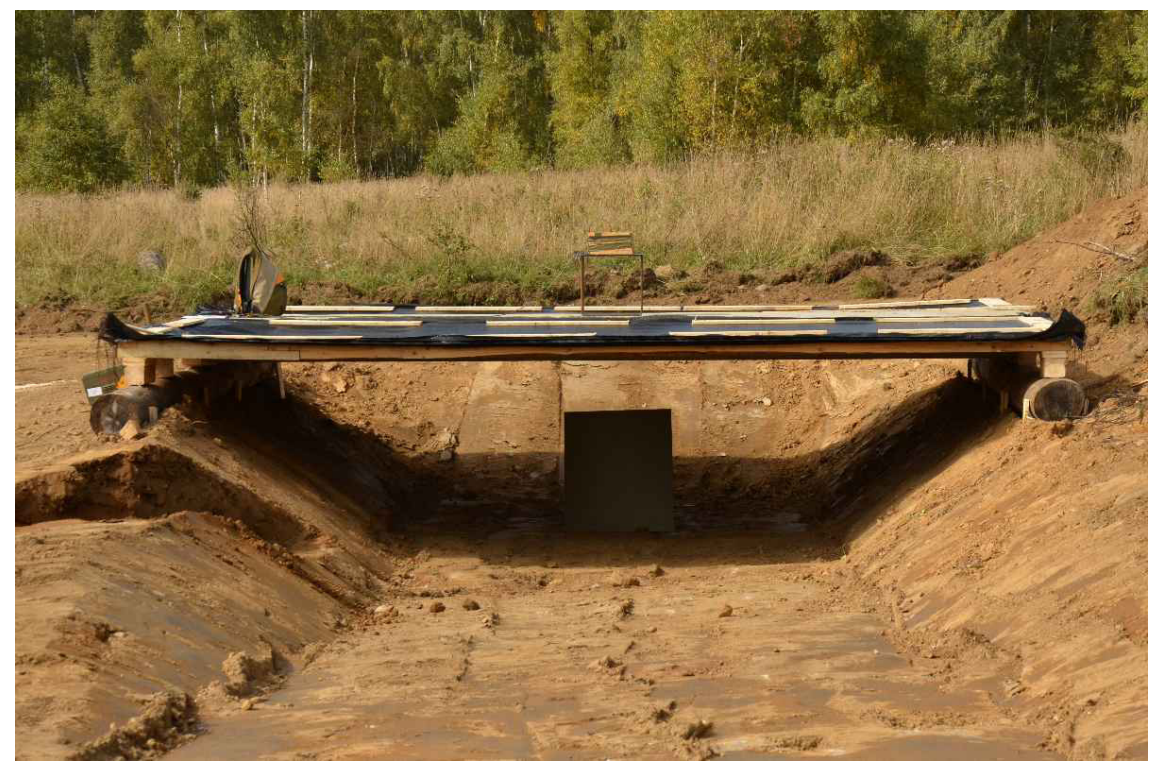

Figure 1: Layout of the experiment.

The timber frame with string grid of $100 \mathrm{~mm}$ was used to measure area and depth of concrete spalling and puncture. The method of data evaluation can be seen in Figure 2. 


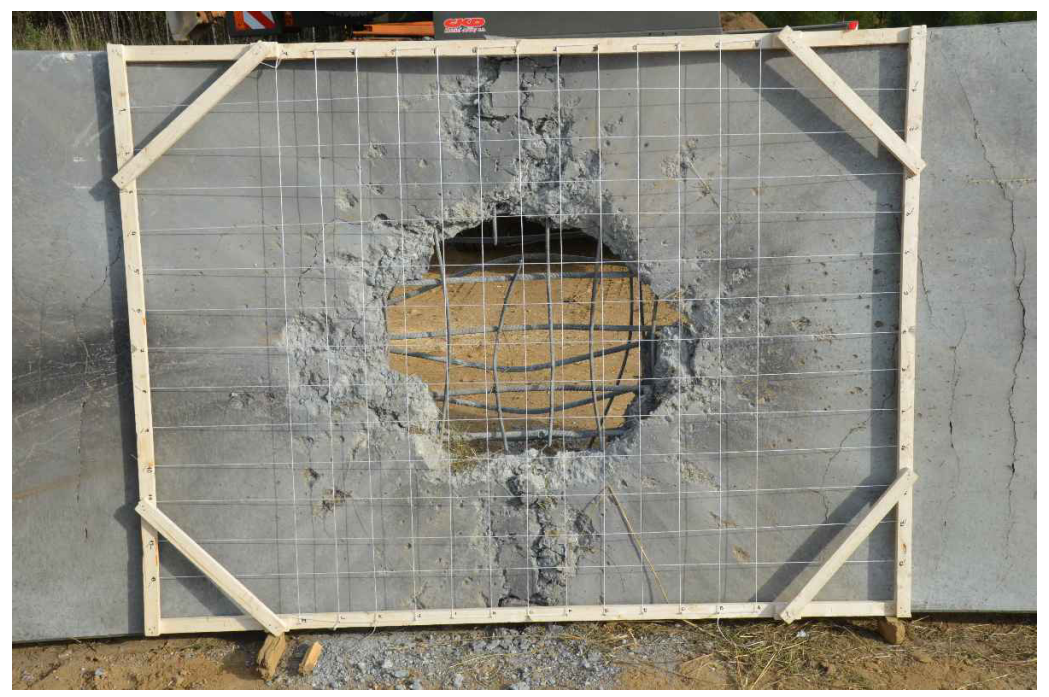

Figure 2: Timber frame with string grid to experiment data evaluation.

\section{Results of the experiment}

The experiments were focused on the effect of fibers (fracture energy), concrete compressive strength and its combination on blast performance of concrete. By means of performance it is understood the dimensions of puncture and spalling of concrete. The differences in puncture and spalling of concrete on the soffit of the slabs can be found in Table 1. In this section, the findings presented in Table 1 are described in detail.

The materials of all specimens were tested for compressive strength. The results of tested cubes can be seen in Table 1 .

The results of the experiment of specimen marked by "**" come from year 2010.

The specimen No. 1 is determined as a reference specimen.

The effect of blast loading on top and bottom surfaces of the specimens can be found in Figures 3-14.

The specimen No. 11, C55/67, $40 \mathrm{~kg} / \mathrm{m}^{3}$ FE fibers, was approximately equally damaged. The area of the puncture is $0.36 \mathrm{~m}^{2}$, volume $0.11 \mathrm{~m}^{3}$, which represents $4 \%$ of the total volume of the specimen. Total volume of the damaged concrete (puncture + spalling) is $0.27 \mathrm{~m}^{3}$, which represents $10 \%$ of the total volume of the specimen. The area of puncture was reduced by $16 \%$ in comparison to specimen No. 1, total volume of damaged concrete was increased by $17 \%$ in comparison to specimen No. 1. The damage of the left side of specimen No. 10 was reduced by more than $80 \%$, the damage of the right side was reduced by more than $65 \%$. The deflection was $320 \mathrm{~mm}$. The shape of deflection was similar to deflection from point loading in the mid-span of the specimen. The deflection was increased by $3 \%$ in comparison to specimen No. 1 . 
Table 1: The results of the experiments.

\begin{tabular}{|c|c|c|c|c|c|c|c|}
\hline Specimen No. & $1 *$ & 6 & 7 & 8 & 9 & 10 & 11 \\
\hline Concrete & C30/37 & $\mathrm{C} 55 / 67$ & $\mathrm{C} 55 / 67$ & $\mathrm{C} 30 / 37$ & $\mathrm{C} 30 / 37$ & $\mathrm{C} 30 / 37$ & $\mathrm{C} 55 / 67$ \\
\hline $\begin{array}{c}\text { Concrete } \\
\text { strength (cube) }\end{array}$ & $\begin{array}{l}49.9 \\
\mathrm{MPa} \\
\end{array}$ & $\begin{array}{l}65.0 \\
\mathrm{MPa} \\
\end{array}$ & $\begin{array}{r}58.3 \\
\mathrm{MPa} \\
\end{array}$ & $\begin{array}{l}45.0 \\
\mathrm{MPa} \\
\end{array}$ & $\begin{array}{l}48.0 \\
\mathrm{MPa} \\
\end{array}$ & $\begin{array}{l}46.5 \\
\mathrm{MPa} \\
\end{array}$ & $\begin{array}{l}65.7 \\
\mathrm{MPa} \\
\end{array}$ \\
\hline Fibers & - & $\begin{array}{c}80 \\
\mathrm{~kg} / \mathrm{m}^{3}\end{array}$ & $\begin{array}{c}40+4.5 \\
\mathrm{~kg} / \mathrm{m}^{3}\end{array}$ & $\begin{array}{l}40+4.5 \\
\mathrm{~kg} / \mathrm{m} 3\end{array}$ & $\begin{array}{c}40 \\
\mathrm{~kg} / \mathrm{m}^{3}\end{array}$ & $\begin{array}{c}80 \\
\mathrm{~kg} / \mathrm{m}^{3}\end{array}$ & $\begin{array}{c}40 \\
\mathrm{~kg} / \mathrm{m}^{3}\end{array}$ \\
\hline $\begin{array}{c}\text { Puncture - top } \\
\text { surface }\end{array}$ & $0.43 \mathrm{~m}^{2}$ & $0.31 \mathrm{~m}^{2}$ & $0.30 \mathrm{~m}^{2}$ & $0.30 \mathrm{~m}^{2}$ & $1.02 \mathrm{~m}^{2}$ & $0.36 \mathrm{~m}^{2}$ & $0.36 \mathrm{~m}^{2}$ \\
\hline $\begin{array}{c}\text { Concrete } \\
\text { spalling (soffit) } \\
-<\text { concrete } \\
\text { cover }\end{array}$ & $2.35 \mathrm{~m}^{2}$ & $1.77 \mathrm{~m}^{2}$ & $1.93 \mathrm{~m}^{2}$ & $1.72 \mathrm{~m}^{2}$ & $2.39 \mathrm{~m}^{2}$ & $1.96 \mathrm{~m}^{2}$ & $2.13 \mathrm{~m}^{2}$ \\
\hline $\begin{array}{c}\text { Concrete } \\
\text { spalling (soffit) } \\
->\text { concrete } \\
\text { cover }\end{array}$ & $1.71 \mathrm{~m}^{2}$ & $1.45 \mathrm{~m}^{2}$ & $1.63 \mathrm{~m}^{2}$ & $1.40 \mathrm{~m}^{2}$ & $2.11 \mathrm{~m}^{2}$ & $1.41 \mathrm{~m}^{2}$ & $1.79 \mathrm{~m}^{2}$ \\
\hline $\begin{array}{c}\text { Concrete } \\
\text { spalling (top } \\
\text { surface) - < } \\
\text { concrete cover }\end{array}$ & $0.43 \mathrm{~m}^{2}$ & $0.83 \mathrm{~m}^{2}$ & $0.67 \mathrm{~m}^{2}$ & $0.77 \mathrm{~m}^{2}$ & $1.30 \mathrm{~m}^{2}$ & $0.78 \mathrm{~m}^{2}$ & $0.87 \mathrm{~m}^{2}$ \\
\hline $\begin{array}{c}\text { Concrete } \\
\text { spalling (top } \\
\text { surface) - }> \\
\text { concrete cover } \\
\end{array}$ & $0.43 \mathrm{~m}^{2}$ & $0.77 \mathrm{~m}^{2}$ & $0.63 \mathrm{~m}^{2}$ & $0.75 \mathrm{~m}^{2}$ & $1.21 \mathrm{~m}^{2}$ & $0.70 \mathrm{~m}^{2}$ & $0.81 \mathrm{~m}^{2}$ \\
\hline $\begin{array}{c}\text { Concrete } \\
\text { spalling (left } \\
\text { side) }-< \\
\text { concrete cover }\end{array}$ & $0.52 \mathrm{~m}^{2}$ & $0.04 \mathrm{~m}^{2}$ & $0.04 \mathrm{~m}^{2}$ & 0 & $0.23 \mathrm{~m}^{2}$ & $0.06 \mathrm{~m}^{2}$ & $0.06 \mathrm{~m}^{2}$ \\
\hline $\begin{array}{c}\text { Concrete } \\
\text { spalling (left } \\
\text { side) - }> \\
\text { concrete cover }\end{array}$ & $0.35 \mathrm{~m}^{2}$ & $0.04 \mathrm{~m}^{2}$ & $0.09 \mathrm{~m}^{2}$ & 0 & $0.37 \mathrm{~m}^{2}$ & 0 & $0.20 \mathrm{~m}^{2}$ \\
\hline $\begin{array}{c}\text { Concrete } \\
\text { spalling (right } \\
\text { side) }-< \\
\text { concrete cover }\end{array}$ & $0.34 \mathrm{~m}^{2}$ & $0.07 \mathrm{~m}^{2}$ & 0 & 0 & $0.24 \mathrm{~m}^{2}$ & $0.11 \mathrm{~m}^{2}$ & $0.06 \mathrm{~m}^{2}$ \\
\hline $\begin{array}{c}\text { Concrete } \\
\text { spalling (right } \\
\text { side) - > } \\
\text { concrete cover }\end{array}$ & $0.23 \mathrm{~m}^{2}$ & $0.11 \mathrm{~m}^{2}$ & $0.05 \mathrm{~m}^{2}$ & $0.05 \mathrm{~m}^{2}$ & $0.30 \mathrm{~m}^{2}$ & $0.17 \mathrm{~m}^{2}$ & $0.14 \mathrm{~m}^{2}$ \\
\hline $\begin{array}{l}\text { Volume of } \\
\text { crushed } \\
\text { concrete }\end{array}$ & $0.23 \mathrm{~m}^{3}$ & $0.20 \mathrm{~m}^{3}$ & $0.25 \mathrm{~m}^{3}$ & $0.26 \mathrm{~m}^{3}$ & $0.45 \mathrm{~m}^{3}$ & $0.24 \mathrm{~m}^{3}$ & $0.27 \mathrm{~m}^{3}$ \\
\hline $\begin{array}{l}\text { Permanent } \\
\text { deflection }\end{array}$ & $0.31 \mathrm{~m}$ & $0.31 \mathrm{~m}$ & $0.30 \mathrm{~m}$ & $0.45 \mathrm{~m}$ & - & $0.45 \mathrm{~m}$ & $0.32 \mathrm{~m}$ \\
\hline
\end{tabular}




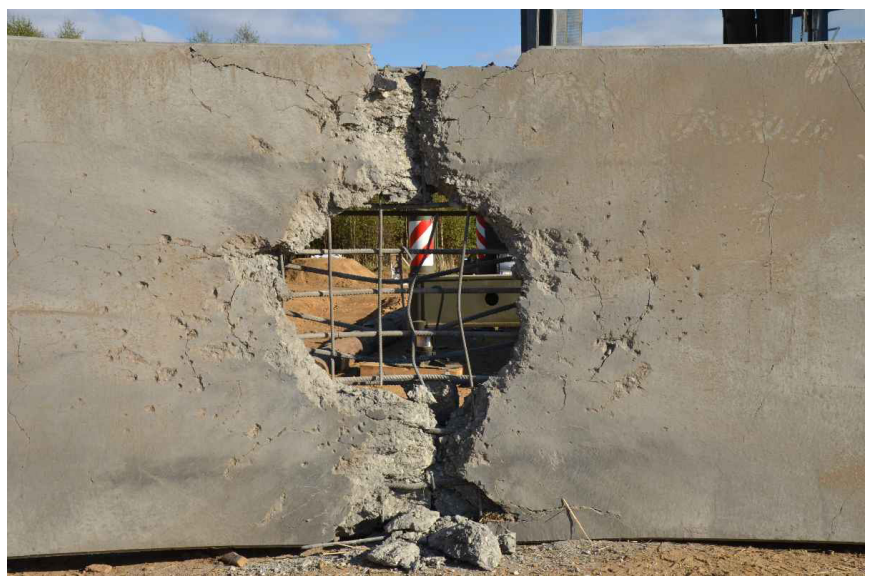

Figure 3: Damaged specimen No. 11 after blast - top view.

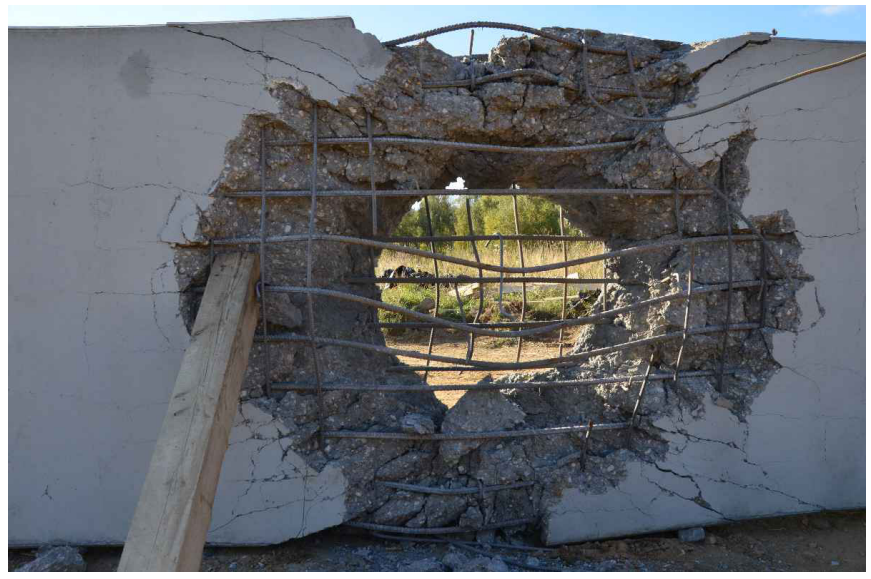

Figure 4: Damaged specimen No. 11 after blast - bottom view.

The specimen No. $10, \mathrm{C} 30 / 37,80 \mathrm{~kg} / \mathrm{m}^{3}$ FE fibers, was approximately equally damaged. The area of the puncture is $0.36 \mathrm{~m}^{2}$, volume $0.11 \mathrm{~m}^{3}$, which represents $4 \%$ of the total volume of the specimen. Total volume of the damaged concrete (puncture + spalling) is $0.24 \mathrm{~m}^{3}$, which represents $8.9 \%$ of the total volume of the specimen. The area of puncture was reduced by $16 \%$ in comparison to specimen No. 1, total volume of damaged concrete was increased by $9 \%$ in comparison to specimen No. 1. The damage of the left side of specimen No. 10 was reduced by more than $85 \%$, the damage of the right side was reduced by more than $75 \%$. The deflection was $450 \mathrm{~mm}$. The shape of deflection was similar to deflection from point loading in the mid-span of the specimen. The deflection was increased by $45 \%$ in comparison to specimen No. 1 . 


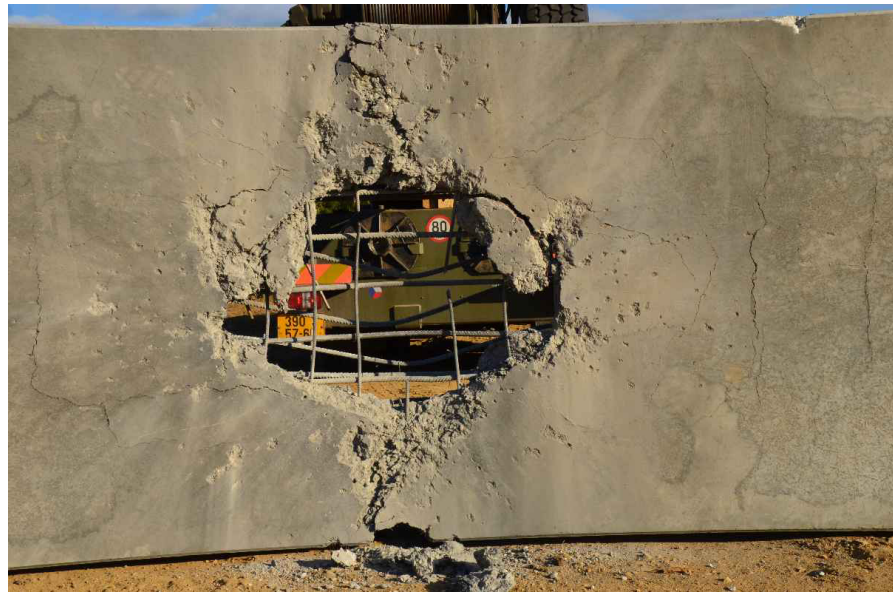

Figure 5: Damaged specimen No. 10 after blast - top view.

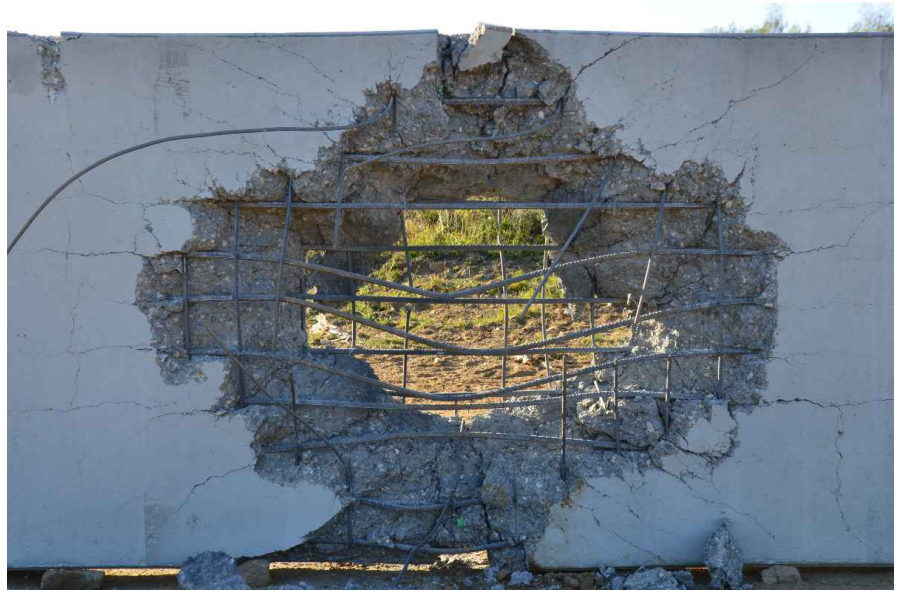

Figure 6: Damaged specimen No. 10 after blast - bottom view.

The specimen No. 9, C30/37, $40 \mathrm{~kg} / \mathrm{m}^{3}$ FE fibers, was completely damaged. The specimen No. 9 after blast can be seen in Fig. 1. The area of the puncture is $1.02 \mathrm{~m}^{2}$, volume $0.31 \mathrm{~m}^{3}$, which represents $11.3 \%$ of the total volume of the specimen. Total volume of the damaged concrete (puncture + spalling) is $0.45 \mathrm{~m}^{3}$, which represents $16.7 \%$ of the total volume of the specimen. The area of puncture was increased by $131 \%$ in comparison to specimen No. 1, total volume of damaged concrete was increased by $95 \%$ in comparison to specimen No. 1 . The damage to the sides was $100 \%$ because area of puncture intervened over the whole width of slab. Cross-section of slab in mid-span was represented by steel reinforcement only. 


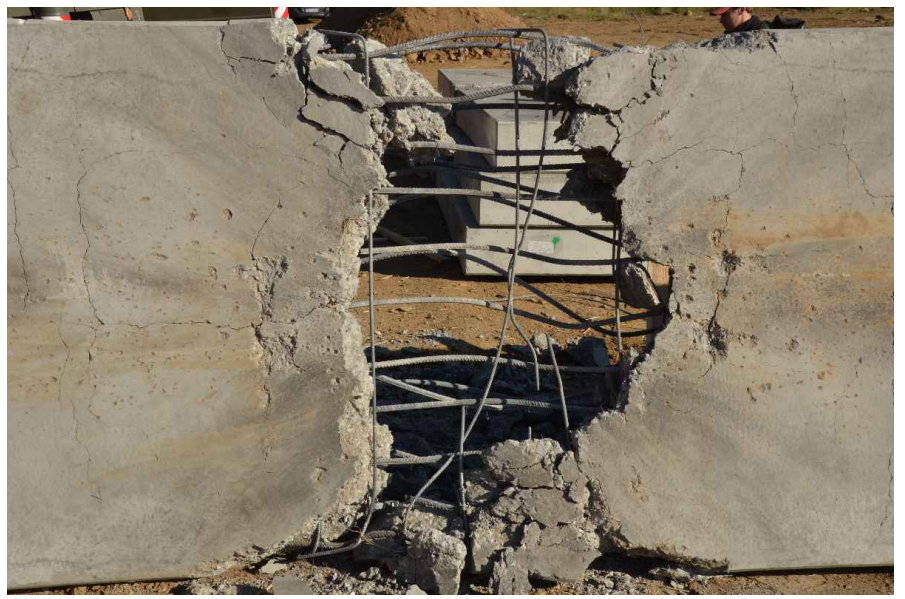

Figure 7: Damaged specimen No. 9 after blast - top view.

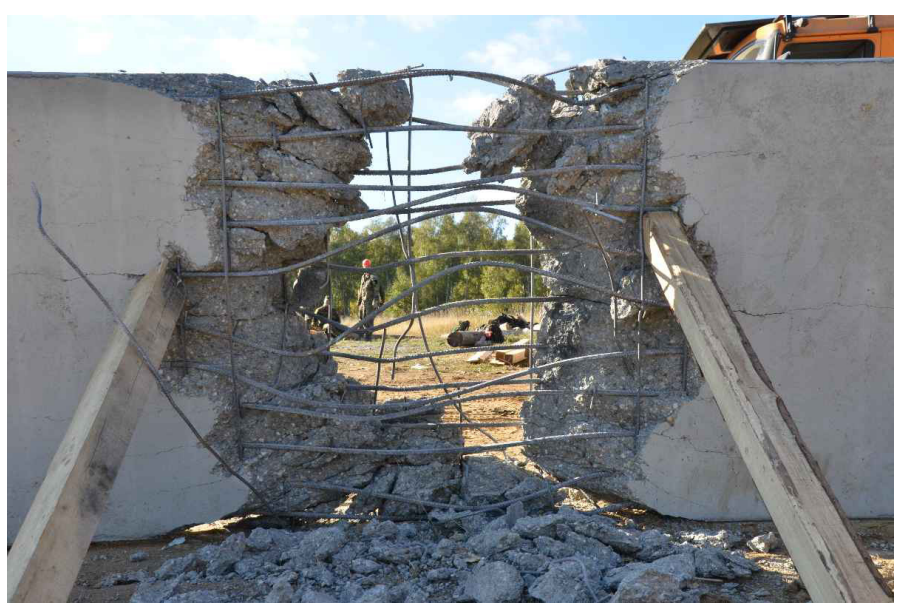

Figure 8: Damaged specimen No. 9 after blast - bottom view.

The specimen No. $8, \mathrm{C} 30 / 37,40 \mathrm{~kg} / \mathrm{m}^{3} \mathrm{FE}+4.5 \mathrm{~kg} / \mathrm{m}^{3}$ PP fibers, was approximately equally damaged. The area of the puncture is $0.30 \mathrm{~m}^{2}$, volume $0.09 \mathrm{~m}^{3}$, which represents $3.3 \%$ of the total volume of the specimen. Total volume of the damaged concrete (puncture + spalling) is $0.26 \mathrm{~m}^{3}$, which represents $9.6 \%$ of the total volume of the specimen. The area of puncture was reduced by $31 \%$ in comparison to specimen No. 1, total volume of damaged concrete was increased by $10 \%$ in comparison to specimen No. 1 . The damage to the sides was completely reduced by $95 \%$. The deflection was $450 \mathrm{~mm}$. The shape of deflection was similar to deflection from point loading in the mid-span of the specimen. The deflection was increased by $45 \%$ in comparison to specimen No. 1. 


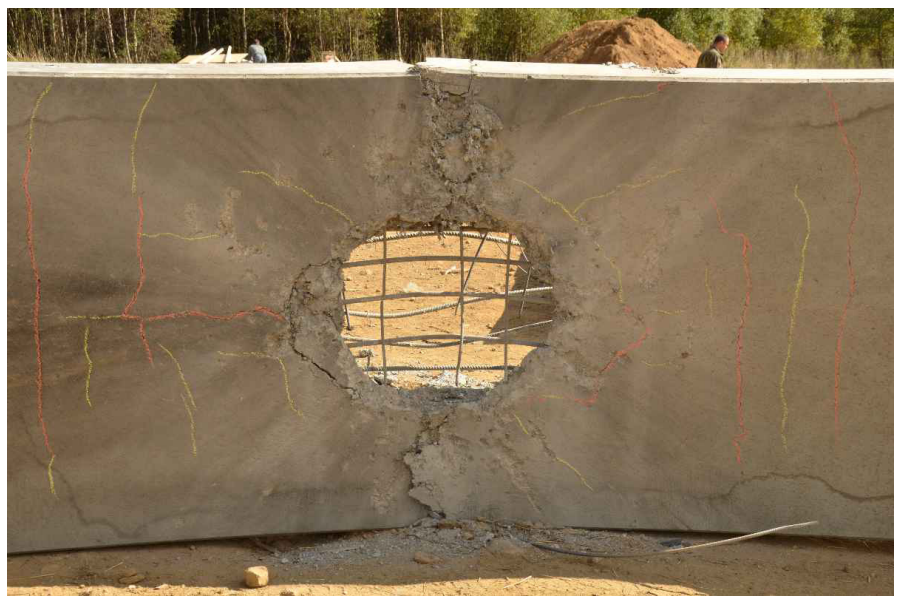

Figure 9: Damaged specimen No. 8 after blast - top view.

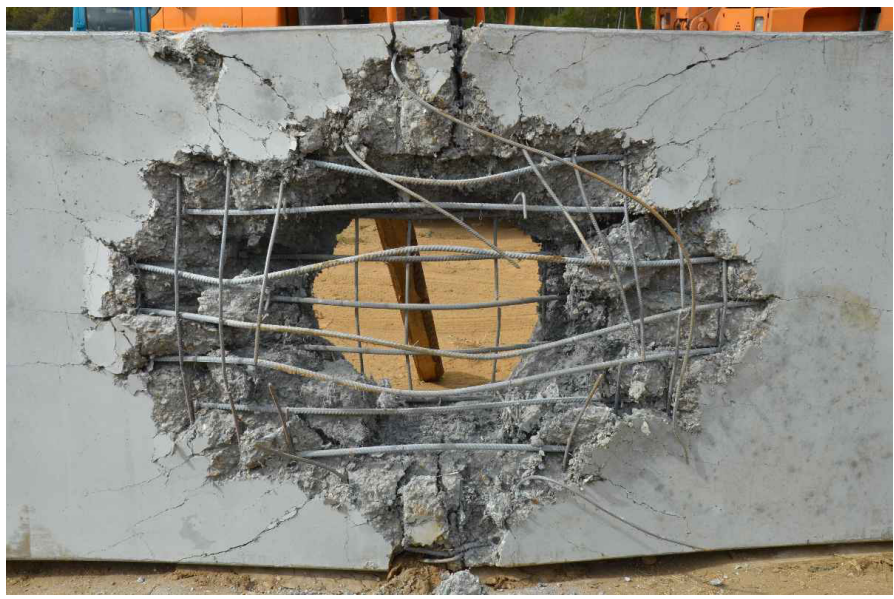

Figure 10: Damaged specimen No. 8 after blast - bottom view.

The specimen No. 7, C55/67, $40 \mathrm{~kg} / \mathrm{m}^{3} \mathrm{FE}+4.5 \mathrm{~kg} / \mathrm{m}^{3}$ PP fibers was approximately equally damaged. The area of the puncture is $0.30 \mathrm{~m}^{2}$, volume $0.09 \mathrm{~m}^{3}$, which represents $3.3 \%$ of the total volume of the specimen. Total volume of the damaged concrete (puncture + spalling) is $0.25 \mathrm{~m}^{3}$, which represents $9.3 \%$ of the total volume of the specimen. The area of puncture was reduced by $31 \%$ in comparison to specimen No. 1, total volume of damaged concrete was increased by $9 \%$ in comparison to specimen No. 1 . The damage to the sides was reduced by $85 \%$. The deflection was $300 \mathrm{~mm}$. The shape of deflection was similar to deflection from point loading in the mid-span of the specimen. The deflection was reduced by $3 \%$ in comparison to specimen No. 1 . 


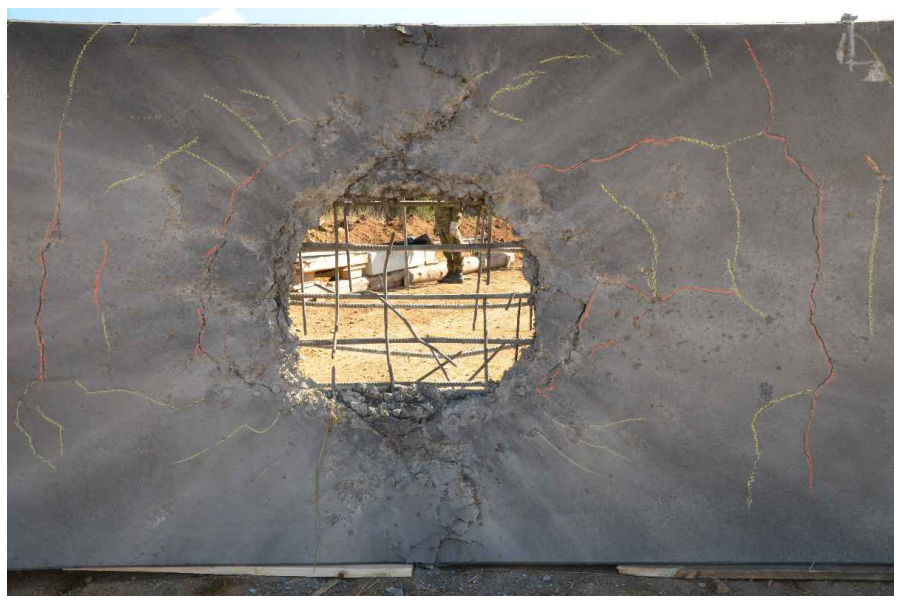

Figure 11: Damaged specimen No. 7 after blast - top view.

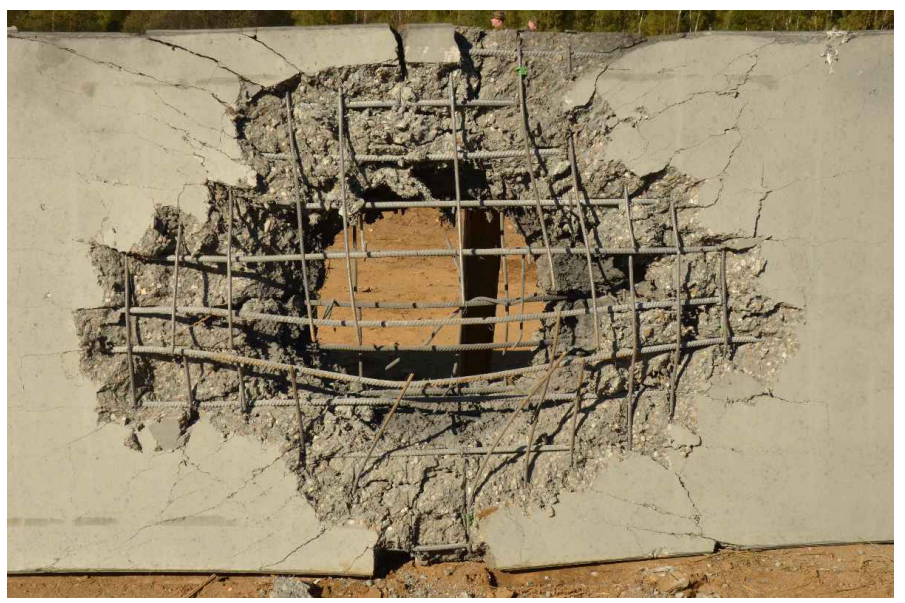

Figure 12: Damaged specimen No. 7 after blast - bottom view.

The specimen No. 6, C55/67, $80 \mathrm{~kg} / \mathrm{m}^{3}$ FE fibers was less damaged. The area of the puncture is $0.31 \mathrm{~m}^{2}$, volume $0.09 \mathrm{~m}^{3}$, which represents $3.4 \%$ of the total volume of the specimen. Total volume of the damaged concrete (puncture + spalling) is $0.20 \mathrm{~m}^{3}$, which represents $7.4 \%$ of the total volume of the specimen. The area of puncture was reduced by $28 \%$ in comparison to specimen No. 1 , the total volume of damaged concrete was reduced by $13 \%$ in comparison to specimen No. 1. The damage of the left side of specimen No. 6 was reduced by more than $80 \%$, the damage of the right side was reduced by more than $50 \%$. The deflection was $310 \mathrm{~mm}$. The shape of deflection was similar to deflection from point loading in the mid-span of the specimen. The deflection was the same in comparison to specimen No. 1 . 


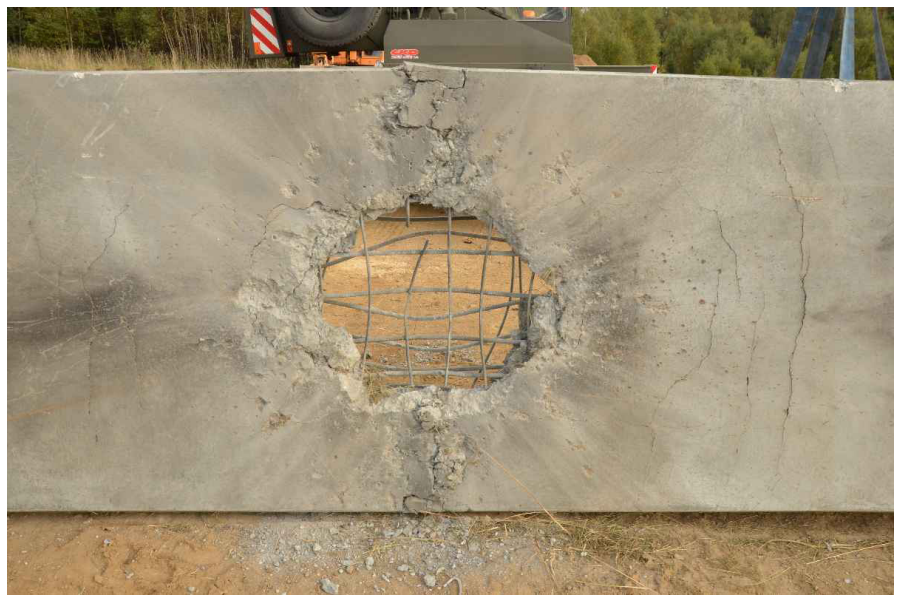

Figure 13: Damaged specimen No. 6 after blast - top view.

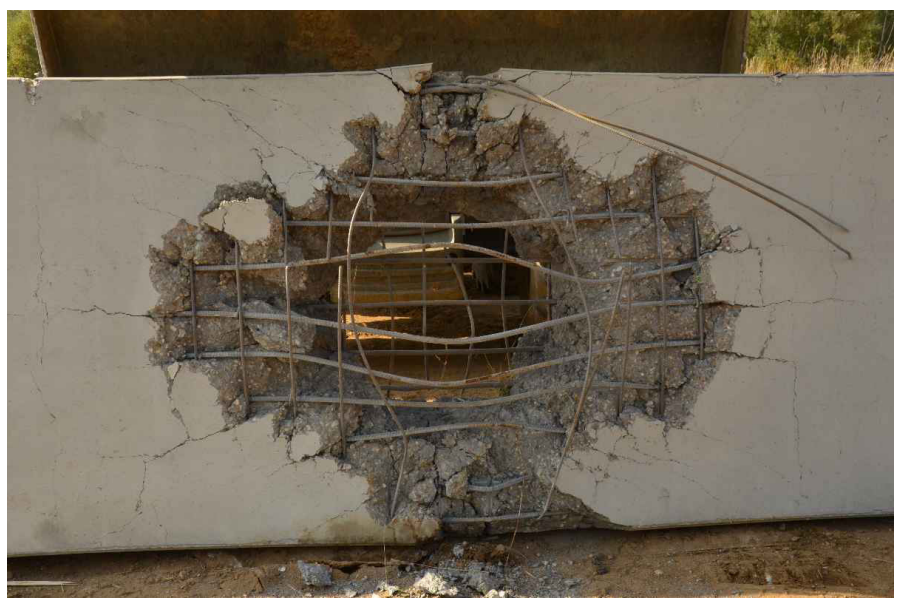

Figure 14: Damaged specimen No. 6 after blast - bottom view.

\section{Conclusions}

Results from the last experiments leading to determine blast performance of fiber reinforced concrete with low ductile steel fibers are described in this paper.

There is no positive effect of added FE fibers to damage of specimens in comparison with reference specimen No. 1.

All specimens (No. 6-11) were more damaged at top surface than reference specimen No. 1.

The extent of damage of all specimens (No. 6-11) was approximately the same as reference specimen No. 1 . 
The extent of damage slightly decreased with increased fiber content, increased fiber strength and increased concrete strength. Combination of shear strength and fracture energy is decisive index of blast performance.

All specimens with PP fibers had better fragmentation properties - less compact fragments flew out after the blast.

\section{Acknowledgement}

This paper was supported by the Grant Agency of the Czech Republic Grant Project No. GAČR13-30441S.

\section{References}

[1] Foglar M., Kovar M., Conclusions from experimental testing of blast resistance of FRC and RC bridge decks, International Journal of Impact Engineering, Volume 59, September 2013, pp. 18-28, ISSN 0734-743X.

[2] Coughlin A.M. et al., Behavior of portable fiber reinforced concrete vehicle barriers subject to blasts from contact charges. International Journal of Impact Engineering, V. 37, No. 5, 2010, pp. 521-529, ISSN 0734-743X.

[3] Tabatabaei Z. S., Volz J. S., Baird J., Gliha B. P., Keener D. I., Experimental and numeric analyses of long carbon fiber reinforced concrete panels exposed to blast loading, International Journal of Impact Engineering, Volume 57, July 2013, pp. 70-80, ISSN 0734-743X. 